\title{
KOMPETENSI KEPALA SEKOLAH SEBAGAI SUPERVISOR DALAM MENINGKATKAN PROFESIONAL GURU PADA SMP NEGERI 2 MESJID RAYA
}

\author{
Nurmalina \\ STAIN Gajah Putih Takengon, Aceh Tengah, Aceh \\ Email: nurmalina125@gmail.com
}

\begin{abstract}
Abstrak. Penelitian ini bertujuan untuk mengetahui peran kompetensi kepala sekolah sebagai supervisor dalam meningkatkan profesional guru pada SMP Negeri 2 Mesjid Raya Kabupaten Aceh Besar. Pendekatan yang digunakan dalam penelitian ini adalah pendekatan deskriptif kualitatif. Subjek dalam penelitian ini adalah kepala sekolah, wakil kepala sekolah dan guru. Teknik pengumpulan data melalui observasi, wawancara dan analisis dokumentasi. Hasil penelitian menunjukkan bahwa Kompetensi kepala sekolah sebagai supervisor harus diwujudkan dalam kemampuan penyusunan dan pelaksanaan program supervisi serta memanfaatkan hasilnya. Aspek-aspek yang akan disupervisi kepala sekolah atau supervisor adalah tentang kelengkapan perangkat pembelajaran diantaranya pengembangan silabus, program tahunan, program semester, KKM, RPP, administrasi yang dibutuhkan di kelas, cara mengajar atau penyampaian materi di kelas. Teknik supervisi yang digunakan oleh kepala sekolah SMP Negeri 2 Mesjid Raya Kabupaten Aceh Besar dalam pelaksanaan superviai adalah teknik supervisi individu dan juga teknik supervisi kelompok. Hambatan-hambatan dalam pelaksanaan supervisi oleh kepala sekolah meliputi: pelaksanaan supervisi tidak sesuai dengan jadwal yang telah ditentukan sebelumnya karena sering terjadi betrokan dengan jadwal lainnya, pengetahuan dan keterampilan kepala sekolah dalam supervisi masih terbatas, masih terdapatnya guru yang belum memahami supervisi. Langkah-langkah yang dilakukan kepala sekolah dalam mengatasi hambatan-hambatan pelaksanaan supervisi adalah melibatkan guru dalam penyusunan jadwal supervisi dan mengadakan kesepakatan dengan guru.
\end{abstract}

Kata kunci: supervisi kepala sekolah, profesional guru.

\section{Pendahuluan}

Upaya meningkatkan kualitas sumber daya manusia di sekolah merupakan tugas seorang pimpinan disebuah sekolah. Seorang pimpinan dalam hal ini kepala sekolah sangat berperan penting dalam meningkatkan mutu pendidikan. Peningkatan mutu dan hasil belajar yang baik tentunya tidak terlepas dari profesinalnya seorang guru. Selain itu pendidikan mempunyai peranan penting dalam upaya meningkatkan kualitas sumber daya manusia sesuai dengan fungsi dan tujuan pendidikan nasional, seperti ditetapkan dalam Undang-Undang RI Nomor 20 taun 2003 tentang Sistem Pendidikan Nasional (2003: 7) pasal 3 berbunyi:

Pendidikan nasional berfungsi mengembangkan kemampuan dan membentuk watak serta peradaban bangsa yang bermartabat dalam rangka mencerdaskan kehidupan bangsa, bertujuan untuk berkembangnya potensi peserta didik agar menjadi manusia yang beriman dan bertaqwa kepada Tuhan Yang Maha Esa, berakhlak mulia, sehat berilmu, cakap, kreatif, mandiri dan menjadi warga negara yang demokratis serta bertanggung jawab.

Menurut Undang-Undang diatas yang dimaksud pendidikan adalah usaha sadar dan terencana untuk mewujudkan suasana belajar dan proses pembelajaran agar peserta 
didik secara aktif mengembangkan potensi dirinya untuk memiliki kekuatan spiritual keagamaan, pengendalian diri, kepribadiaan, kecerdasan, akhlak mulia, serta keterampilan yang diperlukan dirinya, masyarakat, bangsa dan Negara. Dengan adanya pendidikan diharapkan muncul generasi penerus bangsa yang berkualitas dan mampu menyesuaikan diri untuk hidup bermasyarakat, berbangsa dan bernegara.

Tugas seorang guru adalah sebagai pengajar dan pendidik. Sebagai pengajar guru bertugas untuk menuangkan sejumlah bahan pelajaran kepada peserta didik mereka, sedangkan sebagai pendidik guru bertugas untuk membimbing dan membina anak didik agar menjadi manusia yang cakap, aktif, kreatif dan mandiri.Dapat di jabarkan bahwa mengajar maupun mendidik adalah tanggung jawab guru sebagai tenaga professional.Oleh karna itu, tugas berat dari seorang guru pada dasarnya hanya dapat dilakukan oleh guru yang memiliki kompetensi professional yang tinggi.

Peningkatan mutu pendidikan akan berkaitan erat dengan peningkatan kompetensi professional guru, dengan harapan semakin professional seorang guru maka mutu pendidikan akan meningkat. Guru dituntut secara professional untuk terus mengembangkan diri agar dapat mengikuti perkembangan yang cepat dalam bidang ilmu pengetahuan dan teknologi. Guru yang professional adalah mereka para guru yang konsisten memiliki kompetensi yang diperlukan untuk menyelesaikan tugasnya.

Supervisi sebagai suatu kegiatan kepengawasan, yang memiliki tujuan untuk membantu memperbaiki dan meningkatkan pengelolaan pendidikan di sekolah. Supervisi penting untuk dilaksanakan dalam rangka meningkatkan mutu pendidikan khususnya pada proses belajar mengajar. Kegiatan utama pendidikan disekolah dalam rangka mewujudkan tujuannya adalah kegiatan pembelajaran, sehingga seluruh kegiatan organisasi sekolah bermuara pada pencapaian efisiensi dan efektivitas pembelajaran. Sebagaimana diungkapkan oleh Mulyasa (2007 : 111) "Salah satu tugas kepala sekolah adalah sebagai supervisor, yaitu mensupervisi pekerjaan yang dilakukan oleh tenaga kependidikan".Dalam supervisi kepala sekolah mempunyai tugas dan tanggungjawab dalam memajukan pengajaran dengan melalui peningkatan profesi guru secara terus menerus. Kepala sekolah selaku supervisor, disamping harus memiliki pengetahuan serta keterampilan dalam pekerjaan supervisinya, juga memerlukan teknik-teknik supervise tertentu dalam melaksanakan tugas supervisinya. Supervisi yang baik adalah yang dapat mengarahkan perhatiannya kepada dasar-dasar pendidikan dan cara-cara belajar serta perkembangannya dalam pencapaian tujuan umum pendidikan.

Kepala Sekolah adalah pimpinan tertinggi di sekolah. Pola kepemimpinananya akan sangat berpengaruh bahkan sangat menentukan kemajuan sekolah. Sebagaimana yang diungkapkan oleh Yahya (2013: 81) "Peran dan kedudukan kepala sekolah sangat penting dalam meningkatkan mutu pendidikan, terutama dalam menciptakan dan mewujudkan cita-cita dan keberhasilan peserta didik."Salah kompetensi yang harus dimiliki oleh kepala sekolah adalah supervisi.Kepala sekolah sebagai supervisor memegang peranan penting dalam meningkatkan profesionalisme guru di sekolah yang dipimpinnya. Mulyasa (2007 : 23) mengatakan bahwa : "Kepala Sekolah sebagai penanggung jawab terhadap pelaksanaan kegiatan mengajar di sekolah, melalui peranannya sebagai supervisor pengajaran memberikan pelayanan pembinaan profesional kepada guru-guru sangat menentukan keberhasilan program kegiatan belajar mengajar di sekolah".Supervisi atau pengawasan oleh pengawas satuan pendidikan, tentu memiliki misi yang berbeda dengan supervisi yang dilakukan kepala sekolah.Melalui peranannya 
sebagai supervisor kepala sekolah memberikan pelayanan pembinaan profesional kepada guru-guru sangat menentukan keberhasilan program kegiatan belajar mengajar di sekolahdan membantu guru-guru untuk meningkatkan kemampuan profesionalnya..

\section{Metodologi}

Penelitian ini menggunakan pendekatan kualitatif dimana peneliti berusaha untuk mengungkapkan dan memahami kenyataan yang ada di lapangan tentang Kompetensi Kepala Sekolah Sebagai SupervisorDalam Meningkatkan Profesional GuruPada SMP Negeri 2 Mesjid Raya. Adapun yang menjadi subjek atau responden adalah kepala sekolah, wakil kepala dan guru pada SMPN 2 Mesjid Raya.

Teknik pengumpulan data yang digunakan dalam penelitian ini adalah wawancara, observasi dan studi dokumentasi. Dalam penelitian ini peneliti mewawancarai langsung kepala sekolah, wakil kepala sekolah dan guru SMP Negeri 2 Mesjid Raya untuk memperoleh informasi tentang program supervisi, pelaksanaan supervisi kepala sekolah dan hambatan-hambatan yang dihadapi kepala sekolah dalam pelaksanaan supervisi dalam rangka meningkatkan profesional guru SMP Negeri 2 Peukan Bada. Observasi yang dilakukan adalah saat proses belajar mengajar guru di kelas dengan tujuan untuk mengetahui kesiapan guru dalam mengajar seperti perangkat pembelajaran yang digunakan. Studi dokumentasi digunakan untuk melihat program supervisi yang telah dilakukan oleh kepala sekolah dan penilaian supervisi kepala sekolah serta pelaksanaan supervisi yang berkesinambungan setiap tahunnya dalam rangka meningkatkan profesional guru SMP Negeri 2 Mesjid Raya.

Analisis data dalam penelitian ini dilakukan dengan prosedur atau langkah-langkah Miles and Huberman, yaitu reduksi data, penyajian data dan penarikan kesimpulan.Hal tersebut dimaksudkan agar data yang diperoleh sesuai dengan apa yang peneliti harapkan dan sesuai dengan kejadian dilapangan.

\section{Hasil dan Pembahasan}

1. Program Pelaksanaan Supervisi oleh Kepala Sekolah dalam Rangka Meningkatkan Profesioanl Guru pada SMP Negeri 2 Mesjid RayaKabupaten Aceh Besar

Berdasarkan hasil penelitian menunjukkan bahwa SMP Negeri 2 Mesjid Raya Kabupaten Aceh Besar telah melaksanakan supervisi secara rutin dan berjalan baik meskipun masih terdapat hambatan-hambatan. Namun kepala sekolah dengan kompetensi supervisornya mampu meminimalisir hambatan-hambatan tersebut dengan langkahlangkah terbaik dalam melaksanakan supervisi. Demikian juga pelaksanaan program supervisi oleh kepala sekolah mendapat dukungan dari semua pihak, hal ini sesuai dengan paparan hasil penelitian, dimana semua guru telah memberikan dukungan dan bekerja sama untuk pelaksanaan program supervisi dalam rangka meningkatkan profesional guru. Dengan meningkatnya profesional guru secara tidak langsung juga meningkatkan mutu layanan dan mutu lulusan di SMP Negeri 2 Mesjid Raya Kabupaten Aceh Besar.

Berdasarkan Permen Diknas Nomor 13 Tahun 2007 tentang Standar kepala sekolah/Madrasah memngemukakan bahwa ada lima kompetensi yang harus dimiliki kepala sekolah, diantaranya adalah kompetensi supervisi. Kompetensi supervisi meliputi: 1) Merencanakan program supervisi akademik dalam rangka profesionalisme guru; 2) Melaksanakan supervisi akademik terhadap guru dengan menggunakan pendekatan dan teknik supervisi yang tepat; 3) Menindaklanjuti hasil supervisi akademik terhadap guru 
dalam rangka peningkatan profesionalisme guru. Pelaksanaan supervisi oleh kepala sekolah merupakan aktualisasi dari ketiga cakupan kompetensi supervisi tersebut. Perencanaan program supervisi akademik merupakan tahap penyusunan program supervisi (program tahunan dan program semester) dan tahap persiapan, seperti mempersiapkan format instrument supervisi, mempersiapkan materi pembinaan supervisi, mempersiapkan buku catatan, dan mempersiapkan data supervisi sebelumnya. Semua perlengkapan tersebut dibutuhkan pada tahap persiapan.

Pelaksanaan supervisi mengarah pada sasaran yang telah di tetapkan, meliputi langkah-langkah pelaksanaan, observasi dan refleksi. Pelaksanaan program supervisi tidak hanya sebatas melakukan pengontrolan dan mengevaluasi kegiatan pelaksanaan pembelajaran guru akan tetapi mempersiapkan perlengkapan yang dibutuhkan dalam supervisi seperti mempersiapkan perlengkapan format/instrument supervisi, materi pembinaan, data pembinaan sebelumnya sebagai acuan untuk melakukan supervisi lanjutan. Kebiasaan yang dilakukan kepala sekolah memeriksa administrasi guru yang meliputi program tahunan, program semester, KKM, dan RPP. Hal ini hanya bagian dari pelaksanaan supervisi.

Pada hakikatnya peran kepala sekolah sebagai supervisor menurut Pidarta (2009: 18) adalah "membina para guru menjadi profesional dengan mengembangkan hal-hal berikut pada diri setiap guru, yang terdiri dari 1) kepribadian guru; 2) peningkatan profesi secara kontinu; 3) proses pembelajaran; 4) penguasaan materi pembelajaran; 5) keragaman kemampuan guru; 6) keragaman daerah; 7) kemampuan guru dalam bekerja sama dengan masyarakat".

Kepala sekolah dalam kedudukannya sebagai supervisor berkewajiban membina para guru agar menjadi pendidik dan pengajar yang baik. Bagi guruyang sudah baik agar dapat dipertahankan kualitasnya dan bagi guru yang belum baik dapat dikembangkan menjadi lebih baik. Semua guru yang sudah berkompeten maupun yang masih lemah harus diupayakan agar tidak ketinggalan zaman dalam proses pembelajaran maupun materi yang diajarkan. Sebagaimana yang diungkapkan oleh Poerwanto (Kompri, 2017: 219) "tugas kepala sekolah sebagai seorang supervisor berarti ia harus pandai meneliti mencari dan mentukan syarat-syarat mana saja yang diperlukan bagi kemajuan sekolahnya sehingga tujuan pendidikan di sekolah itu dapat dicapai secara maksimal”. Kepala sekolah harus dapat meneliti dan menentukan syarat-syarat mana yang telah ada dan mencukupi, mana yang belum ada dan kurang mencukupi yang perlu diusahakan dan dipenuhi untuk mencapai hasil yang yang maksimal.

Kegiatan supervisi yang berkesinambungan sangat diperlukan agar semua kegiatan sekolah dapat berjalan baik dan lancar. Kegiatan supervisi dilakukan bukan untuk mencari kesalahan, akan tetapi membantu guru-guru dalam menjalankan tugasnya. Sebagaimana yang disebutkan dalam Peraturan Pemerintah Nomor 19 Tahun 2005 Pasal 57 yaitu "supervisi meliputi supervisi manjerial dan akademik dilakukan secara teratur dan berkesinambungan oleh pengawas satuan pendidikan dan kepala sekolah satuan pendidikan". Kompri (2017:219) juga menyatakan bahwa "pendidikan akan berkualitas jika guru-gurunya profesional dan berkualitas. Guru-guru akan profesional dan berkualitas jika ada yang membimbing, yang menggerakkan dan memimpinnya untuk meningkatkan dan mengembangkan profesionalitasnya. Bimbingan seperti inilah yang merupakan supervisi kepala sekolah”. 
Setiap pelaksanaan program pendidikan merupakan adanya pengawasan atau supervisi. Pengawasan atau supervisi pendidikan berperan penting dalam membantu kegiatan pelaksanaan pendidikan yang dilakukan oleh guru untuk meningkatkan kemampuan mereka dalam meningkatkan mutu dan mengatasi masalah pembelajaran yang dihadapi guru. Sebagaimana Pidarta (2009: 50) mengatakan: Setiap supervisor memiliki program sendiri-sendiri dalam melaksanakan tugasnya, namun secara umum, program supervisor itu adalah sebagai berikut: 1) analisis kemampuan guru; 2) penelitian dan pengembangan proses pembelajaran; 3) pembinaan guru secara preventif dan kuratif; 4) hubungan masyarakat dan analisis kebutuhan daerah dan; 5) mengembangkan kurikulum lokal. Kurikulum local dimaksud perencanaan pembelajaran yang dikemas sesuai lingkungan sekolah berada.

Program supervisi yang dilakukan kepala sekolah dapat meningkatkan profesional guru. Pelaksanaan program tersebut harus sesuai dengan apa yang telah dirumuskan, sehingga apa yang direncanakan akan lebih efektif dan tercapai tujuan yang telah ditetapkan sebelumnya. Agar kegiatan supervisi yang dilaksanakan supervisor benarbenar sesuai dengan kebutuhan nyata di lapangan, maka program yang disusun harus realistik yang dikembangkan berdasarkan kebutuhan setempat.

Berdasarkan hasil penelitian dapat kita ketahui bahwa proses penyusunan program pelaksanaan supervisi pada SMP Negeri 2 Mesjid Raya Kabupaten Aceh Besar semua guru dilibatkan dan saling kerja sama, sehingga pelaksanaan program supervisi terlaksana dengan baik dan lancar. Kepala sekolah dengan guru mempunyai koordinasi dan pemahaman yang tinggi tentang pelaksanaan program supervisi dalam rangka meningkatkan profesional di SMP Negeri 2 Mesjid Raya.

2. Teknik-teknik Pelaksanaan Supervisi oleh Kepala Sekolah dalam Rangka Meningkatkan Profesional Guru pada SMP Negeri 2 Mesjid RayaKabupaten Aceh Besar

Berdasarkan hasil penelitian diketahui bahwa kepala sekolah dalam rangka meningkatkan profesional guru melakukan supervisi dengan menggunakan teknik supervisi individu dan teknik supervisi kelompok. Kepala sekolah melakukan observasi kunjungan kelas dan pertemuan-pertemuan dengan para guru. Observasi kelas biasanya dilakukan kepala sekolah untuk menindak lanjuti kesepakatan yang telah dibicarakan sebelumnya. Teknik-teknik supervisi tersebut dilakukan kepala sekolah untuk mengidentifikasi masalah-masalah yang berhubungan dengan proses pembelajaran. Hal ini sesuai dengan yang dikemukakan oleh Purwanto (Kompri, 2017: 223) yaitu: Teknik yang digunakan dalam melaksanakan supervisi oleh kepala sekolah terhadap guru-guru dan pegawai sekolah dapat dilakukan dengan teknik perseorangan dan teknik kelompok. Kegiatan yang termasuk teknik perseorangan adalah mengadakan kunjungan kelas, kunjungan observasi, membimbing guru-guru tentang cara-cara mempelajari pribadi siswa atau mengatasi problema yang dihadapi oleh siswa, menghadapi guru-guru dalam hal-hal yang berhubungna dengan pelaksanaan kurikulum sekolah. Adapun yang termasuk kelompok sekolah adalah mengadakan pertemuan atau rapat dengan guru-guru untuk membicarakan berbagai hal yang berhubungan dengan proses dan hasil pembelajaran, mengadakan dan membimbing diskusi kelompok diantara guru-guru bidang studi, memberikan kesempatan kepada guru-guru untuk mengikuti penataran yang 
sesuai dengan bidang tugasnya dan membimbing guru-guru dalam mempraktikkan hasilhasil penataranyang telah diikuti.

Salah satu cara kepala sekolah untuk membina guru dalam kegiatan pembelajaran siswa adalah melalui pelaksanaan supervisi dengan menggunakan teknik-teknik supervisi. Teknik-teknik supervisi tersebut adalah teknik supervisi individu dan teknik supervisi kelompok. Melalui teknik-teknik supervisi kepala sekolah dapat membntu guru untuk memecahkan permasalahan yang ditemukan dalam proses pembelajaran.

Teknik-teknik supervisi sangat diperlukan oleh kepala sekolah dalam meningkatkan profesional guru. Sebagaiman yang dikatakan oleh Susanto (2016: 233) yaitu untuk mencapai tujuan dari supervisi akademik, seorang supervisor dapat menggunakan berbagai teknik, antara lain teknik perseorangan dan teknik kelompok. Teknik perseorangan dalam kegiatan supervisi adalah bantuan yang dilakukan secar mandiri oleh supervisor baik yang terjadi dalam kelas maupun di luar kelas. Maksud dari teknik perseorangna ini, yaitu Pertama, mengadakan kunjungan kelas, baik ketika kegiatan pembejaran berlangsung untuk mengamati guru yang sedang mengajar, ataupun ketika kelas kosong atau sedang berisi siswa tetapi guru tidak mengajar. Tujuannya untuk mengobservasi bagaimana guru mengajar, apakah sudah memenuhi syarat-syarat didaktis atau metodik yang sesuai. Kedua, mengadakan kunjungan observasi yaitu guru-guru dari suatu sekolah sengaja ditugaskan untuk melihat/mengamati seorang guru yang sedang mendemonstrasikan cara-cara mengajar suatu mata pelajaran tertentu. Kunjungan observasi ini juga diikuti dengan mengadakan diskusi di antara guru-guru penamat dan demonstran. Ketiga, membimbing guru tentang cara-cara mempelajari pribadi siswa dana tau mengatasi problema yang dialami siswa; Keempat, membimbing guru-guru dalam hal-hal yang berhubungan dengan pelaksanaan kurikulum sekolah. Sedangkan teknik kelompok meliputi: 1) mengadakan pertemuan atau rapat; 2) mengadakan diskusi kelompok; 3) mengadakan penataran; 4) Mengadakan seminar.

Berdasarkan pendapat ahli di atas dapat disimpulkan bahwa pelaksaan supervisi adalah sebagai suatu kegiatan untuk membantu guru dalam pelaksanaan kegiatan belajar mengajar, yaitu kegiatan dalam menciptakan situasi yang kondusif sehingga peserta didik dapat belajar dengan baik. Oleh karena itu dalam pelaksanaan supervisi diperlukan berbagai teknik-teknik supervisi sesuai dngan kebutuhan guru untuk mencapai tujuan pendidikan sekolah secara efektif dan efisien. Teknik-teknik supervisi yang sering digunakan kepala sekolah dalam pelaksanaan supervisi di sekolah adalah teknik individual/perseorangan dan teknik kelompok. Teknik individual/perseorangan merupakan teknik yang digunakan pada pribadi yang mengalami masalah khusus dan memerlukan bimbingan tersendiri dari kepala sekolah. Sedangkan orang-orang yang diduga mempunyai masalah yang sama dapat dihadapi secar bersama-sama dalam suatu situasi oleh supervisor/kepala sekolah.

Menurut Tim Dosen Administrasi Pendidikan Universitas Pendidikan Indonesia (2015: 325) mengungkapkan bahwa kegiatan supervisi merupakan proses aktivitas untuk meningkatkan kemampuan profesional guru, dalam jangka panjang bertujuan untuk meningkatkan dan mempertahankan kemajuan belajar anak. Sasaran program supervisi ditunjukkan langsung kepada guru yang melayani kegiatan belajar, namun demikian program supervisi juga memperhatikan pertumbuhan belajar murid. Maka pada hakikatnya supervisi pendidikan dapat diartikan sebagai bimbingan profesional bagi guru-guru. Dalam pelaksanaan supervisi perlu pemahaman dan keterampilan yang 
profesional. Professional dalam mengorganisasi guru, menguasai teknik-teknik supervisi, dan memiliki prilaku etik yang baik.

Berdasarkan pendapat ahli di atas dapat disimpulkan bahwa dalam pelaksanaan supervisi yang dilakukan kepala sekolah merupakan suatu aktivitas untuk meningkatkan profesional guru. Kepala sekolah dalam melaksanakan supervisi memerlukan teknikteknik baik individual maupun kelompok untuk mencapai tujuan pendidikan sekolah yang telah ditentukan dan juga untuk memotivasi serta meningkatkan profesional guru.

3. Hambatan-hambatan Kepala Sekolah dalam Pelaksanaan Supervisi untuk Meningkatkan Profesiona Guru pada SMP Negeri 2 Mesjid Raya

Lancar tidaknya suatu sekolah dan tinggi rendahnya mutu sekolah tidak hanya ditentukan oleh jumlah guru dan kecakapan-kecakapannya, tetapi lebih banyak ditentukan oleh cara kepala sekolah melaksanakan kepemimpinan di sekolahnya. Untuk melaksanakan supervisi dan untuk menigkatkan mutu pendidikan sekolah, kepala sekolah harus mengetahui bagaimana cara memanfaatkan kesanggupan guru-gurunya dan dapat mengikutsertakan semua potensi yang ada dalam organisasi sekolah yang dipimpinnya.

Kompetensi supervisi kepala sekolah SMP Negeri 2 Mesjid Raya Kabupaten Aceh Besar dalam rangka meningkatkan profesioanl guru sudah baik. Ini dapat dilihat dari adanya program supervisi yang telah dirumuskan, penggunaan teknik-teknik supervisi dalam pelaksanaan supervisi kepala sekolah, akan tetapi masih ada hambatan-hambatan yang dialami kepala sekolah dan guru dalam pelaksanaan program supervisi. Kompri (2017: 233) mengemukakan bahwa: faktor-faktor yang mempengaruhi berhasil tidaknya supervisi atau cepat lambatnya hasil supervisi, antara lain: 1) lingkungan masyarakat tempat sekolah berada; 2) besar kecilnya sekolah yang menjadi tanggung jawab kepala sekolah; 3) tingkatan dan jenis; 4) keadaan guru-guru dan pegawai yang tersedia; 5) kecakapan dan keahlian kepala sekolah itu sendiri.

Dari lima faktor yang memengaruhi berhasil tidaknya pelaksanaan supervisi, faktor yang terpenting adalah kecakapan dan keahlian kepala sekolah itu sendiri. Bagimanapun baiknya situasi dan kondisi yang tersedia, jika kepala sekolah itu sendiri tidak mempunyai kecakapan dan keahlian yang diperlukan, semuanya tidak akan ada artinya. Sebaliknya adanya kecakapan dan keahlian yang dimiliki oleh kepala sekolah, segala kekurangan yang akan ada menjadi perangsang yang mendorongnya untuk selalu berusaha memperbaiki dan menyempurnakannya.

Dari hasil penelitian menunjukkan hambatan-hambatan dalam pelaksanaan supervisi meliputi: 1) Pelaksanaan supervisi tidak sesuai dengan jadwal yang telah ditentukan sebelumnya karena sering terjadi betrokan dengan jadwal lainnya. Padatnya kegiatan yang harus dilakukan kepala sekolah menyebabkan supervisi tidak sesuai dengan jadwal yang telah disepakati; 2) Pengetahuan dan keterampilan kepala sekolah dalam supervisi masih terbatas; 3) Masih terdapatnya guru yang belum memahami supervisi, sehingga kurang mendapat dukungan dalam pelaksanaan supervisi kepala sekolah. Menurut Basri (2015: 102) mengemukakan bahwa adapun faktor-faktor yang menghambat efektivitas dan efisiensi penyelenggaraan pendidikan yang sering dihadapi dalam pelaksanaan supervisi datang dari berbagai pihak, yaitu dari pihak guru, dari pihak anak didik, dari pihak sarana dan dari pihak kepala sekolah. Faktor penghambat supervisi dari pihak guru meliputi: 1) kurang adanya semangat kerja; 2) kurang kesediaan bekerja sama dan 
berkomunikasi; 3) kurang kecakapan dalam melaksanakan tugas; 4) kurang menguasai metode mengajar; 5) kurang memahami tujuan dan program kerja; 6) kurang menaati peraturan ketertiban. Faktor penghambat dari pihak anak didik meliputi: 1) kurang kerajinan dan ketekunan; 2) kurang menaati ketertiban; 3) kurang adanya kesadaran perlunya belajar. Faktor penghambat dari pihak prasarana meliputi: 1) kurang terpenuhinya syarat-syarat tentang gedung, halaman, kesehatan, keamanan; 2) kurang tersedianya alat-alat pelajaran, seperti bangku, kursi, lemari, papan tulis. Faktor penghabat dari pihak kepala sekolah meliputi: 1) kurang adanya tanggung jawab pengabdian; 2) kurang kewibawaan dan pengetahuan; 3) terlalu otoriter; 4) terlalu lunak, bersikap masa bodo.

Tim dosen Administrasi Pendidikan Universitas Pendidikan Indoensia (2015: 324) juga mengemukan masalah-masalah yang menghambat terlaksananya supervisi, diantaranya 1) sistem kerja sentralisasi yang masih melekat; 2) persaingan mutu sekolah semakin berat; 3) masih adanya mental anak emas untuk guru yang dinilai baik; 4) tuntutan akuntabilitas penyelenggaraan sekolah dari masyarakat yang semakin tinggi; 5) transparansi manajemen sekolah yang sering terjadi benturan kebijakan dengan komite sekolah; 6) transparansi pengelolaan keuangan sekolah yang pembukuan dan buktibuktinya menyita banyak waktu.

Berdasarkan pendapat ahli di atas dapat disimpulkan bahwa faktor penghambat pelaksanaan supervisi muncul dari berbagai pihak, yaitu dari pihak guu, anak didik, prasarana dan juga dari kepala sekolah itu sendiri. Kepala sekolah sebagai pemimpin dan supervisor mempunyai wewenang dan tanggung jawab dalam pengembangan dan pembinaan pendidikan, yang berkaitan dengan proses belajar mengajr dan kurikulum dengan semua pelaksanaannya. Dalam menjalankan fungsinya sebagai supervisor kepala sekolah harus mampu menguasai dan melaksanakan tugasnya dengan baik.

Namun faktor penghambat dalam pelaksanaan supervisi selalu ada, sebagaimana yang dikatakan oleh Priansa (2014: 104) yaitu "faktor yang berpengaruh terhadap kinerja kepala sekolah sebagai seorang supervisor diantaranya kondisi pribadi kepala sekolah, organisasi sekolah, dan lingkungan eksternal". Kepala sekolah bertanggung jawab terhadap seluruh kegiatan sekolah, mengatur proses belajar mengajar, mengatur hal-hal yng menyangkut kesiswaan, personalia, sarana dan prasarana yang dibutuhkan dalam pelajaran, ketatusahaan, keuangan serta mengatur hubungan dengan masyarakat.

Tim Dosen Administrasi Pendidikan Universitas Pendidikan Indonesia (2015: 324) mengatakan bahwa usaha untuk kelancaran dan keberhasilan pemecahan masalah yang ditempuh dalam kegiatan supervisi oleh kepala sekolah adalah sebagai berikut: 1) penyamaan visi dan misi; 2) pengelolaan supervisi yang baik; 3) pelibatan guru secara individual dalam pelaksanaan supervisi; 4) pelibatan organisasi guru, seperti PKG, KKG dan KKS untuk mengukur keberhasilan guru dalam pembelajaran dan sebagai tempat sharring.

Dalam melaksanakan supervisi terhadap guru-guru dibutuhkan dorongan dari supervisor, sehingga guru-guru merasa yakin bahwa mereka mampu untuk berbuat lebih baik. Supervisi yang diprogramkan kepala sekolah dilaksanakan secara berkesinambungan. Usaha memenuhi kebutuhan tenaga pendidik dengan cara memperhatikan kondisi fisik, memberikan rasa aman, menunjukkan bahwa kepala sekolah memperhatikan mereka sedemikian rupa, sehingga setiap guru pernah 
memperoleh kepuasan dan penghargaan. Melalui penghargaan para guru dapat dirangsang untuk meningkatkan profesionalisme kerjanya secara positif dan produktif.

\section{Kesimpulan}

Program supervisi disusun oleh pimpinan sekolah yang melibatkan staf pengajar, aspek-aspek yang akan disupervisi adalah kelengkapan perangkat pembelajaran. SMP Negeri 2 Mesjid Raya Aceh Besar menunjukkan bahwa Kemampuan seorang pimpinan sekolah sebagai pengamat proses pengajaran di kelas sangatlah berperan penting dalam meningkatkan kompetensi kemampuan mengajarnya sebagai pengajar. Pelaksanaan supervisi merupakan acuan kepala sekolah untuk mengembangkan profesional guru dalam peningkatan mutu guru dan PBM didalam kelas. Supervisi merupakan alat yang digunakan seorang pengamat pembelajaran didalam kelas atau sering disebut supervisor untuk mentreatmen stafnya dalam pelaksanaan pengajaran dikelas. Sehingga pelaksanaan dan harapan yang ditargetkan akan tercapai.

Pelaksanaan supervisi biasanya dilaksanakan dalam tiga tahap yaitu: pra observasi, observasi dan pasca observasi. Pelaksanaan pra observasi berlangsung sebelum pelaksanaan obsevasi di dalam kelas. Dalam hal ini seorang kepala sekolah sebagai supervisor melakukan pertemuan dengan guru sasaran yang akan disupervisi untuk membahas tentang PBM yang akan dilaksanakan didalam kelas. Sebelum PBM berlangsung seorang kepala sekolah harus menelaah RPP termasuk penilaian saat proses terjadi. Selanjutnya observasi, dimana pengamatan langsung yang dilakukan oleh seorang kepala sekolah selaku supervisor untuk melihat apakah RPP yang ditelaah sebelumnya dapat direalisasikan kedalam PBM. Dan yang terkhir adalah pasca observasi yang merupakan pembicaraan antara supervisor dan guru untuk mengevaluasi PBM yang telah berlangsung. Melalui rubrik penilaian maka akan disampaikan oleh supervisor dalam hal ini kepala sekolah, apa saja yang telah tercapai dan yang belum tercapai saat PBM berlagsung kepada guru yg disupervisi. Berdasarkan nilai maka seorang kepala sekolah yang berfungsi sebagai supervisor dapat mengambil tindakan langkah apa yang diambil untuk mengembangkan dan memprofesionalkan guru tersebut.

Hambatan pelaksanaan supervisi kepala sekolah meliputi: terjadinya bentrokan waktu pelaksanaan supervisi di dalam kelas dengan jadwal lainnya, pengetahuan dan keterampilan kepala sekolah terhadap supervisi masih terbatas, masih terdapatnya guru yang belum memahami supervisi dan fungsinya. Hambatan dalam pelaksanaan supervisi kepala sekolah adalah kepala sekolah itu sendiri, pada dasarnya semua program yang telah susun oleh kepala sekolah bersama para guru semestinya harus terlaksana secara keseluruhan dengan harapan hasil yang sangat memuaskan. Akan tetapi dalam pelaksanaa pergeseran jadwal dan waktu sering kurang tepat. Itu semua dikarenakan bentroknya jadwal kepala sekolah yang tidak terencana sebelumnya, misalnya rapat dinas dan lain sebagainya.

\section{Daftar Pustaka}

Basri, Hasan dan Tatang. (2015). Kepimpinan Pendidikan. Bandung: Pustaka Setia Fathurrohman, Pupuh dan Aa Suryana. (2015). Supervisi Pendidikan. Bandung: Refika Aditama

Kompri. (2017). Standarisasi Kompetensi Kepala Sekolah Pendekatan Teori untuk Praktik Profesional. Jakarta: Kencana 
Muslim, Sri Banun. (2013). Supervisi Pendidikan Meningkatkan Kualitas Profesionalisme Guru. Bandung: Alfabeta

Mulyasa, E. (2013). Menjadi Guru Professional Menciptakan Pembelajaran Kreatif dan Menyenangkan. Bandung: Remaja Rosdakarya

\section{Rosdakarya}

(2013). Menjadi Kepala Sekolah Profesional. Bandung: Remaja

Permen Diknas Nomor 13 Tahun 2007 tentang Standar Kepala Sekolah/Madrasah

Pidarta, Made. (2009). Supervisi Pendidikan Kontekstual. Jakarta: Rineka Cipta

Priansa, Donni Juni dan Rismi Somad. (2014). Manajemen Supervisi dan Kepemimpinan Kepala Sekolah. Bandung: Alfabeta

Rohiat. (2010). Manajemen Sekolah. Bandung: Refika Aditama

Rusman. (2012). Model-model Pembelajaran Mengembangkan Profesional Guru. Jakarta: Raja Grafindo Persada

Sugiyono. (2014). Metode Penelitian Pendekatan Kuantitatif, Kualitatif, dan $R \& D$. Bandung: Alfabeta

Susanto, Ahmad. (2016). Konsep, Strategi, dan Implementasi Manajemen Peningkatan Kinerja Guru. Jakarta: Kencana

Tim Dosen Administrasi Pendidikan Universitas Pendidikan Indonesia. (2015). Manajemen Pendidikan. Bandung: Alfabeta

Undang-undang Guru dan Dosen No. 14 tahun 2005, serta PP No.19 tahun 2005 tentang Standar Nasional Pendidikan

Wahjosumidjo. (2013). Kepemimpinan Kepala Sekolah Tinjauan Teoritik dan Permaslahannya. Jakarta: Raja Grafindo Persada

Yahya, Murip. (2013). Profesi Tenaga Kependidikan. Bandung: Pustaka Setia 